\title{
Technical and Economic Feasibility of Partitioning Hanford Purex Process Acid Waste
}

May 1975

Prepared for the U.S. Energy Research and Development Administration under Contract AT(45-1):1830 


\title{
NOTICE
}

This report was prepared as an account of work sponsored by the United States Government. Neither the United States nor the United States Atomic Energy Commission, nor any of their employees, nor any of their contractors, subcontractors, or thier employees, makes any warranty, express or implied, or assumes any legal liability or responsibility for the accuracy, completeness or usefulness of any information, apparatus, product or process disclosed, or represents that its use would not infringe privately owned rights.

PACIFIC NORTHWEST LABORATORY operated by

BATTELLE

for the

U.S. ATOMIC ENERGY COMMISSION

Under Contract AT(45-1)-1830

\author{
Printed in the United States of America \\ Available from \\ Nationaf Technical Information Service \\ U.S. Department of Commerce \\ 5285 Port Royal Road \\ Springfield, Virginia 22151
}

Price: Printed Copy \$7.60; Microfische \$2.25 
BNWL-1907

UC-70,

Waste Management

\title{
TECHNICAL AND ECONOMIC FEASIBILITY OF PARTITIONING KANFORD PUREX PROCESS
}

\section{ACID WASTE}
R. E. Burns
J. N. Hartley
D. H. Lester
F. P. Roberts
J. L. Swanson
E. J. Wheelwright

May 1975

On January 19, 1975, research and development programs of the U.S. Atomic Energy Commission (AEC) became part of the newly formed Energy Research and Development Administration (ERDA). In this report, since it refers to work done in 1974, most references are to AEC programs.

\author{
Battelle \\ Pacific Northwest Laboratories \\ Richland, Washington 99352
}




\section{CONTENTS}

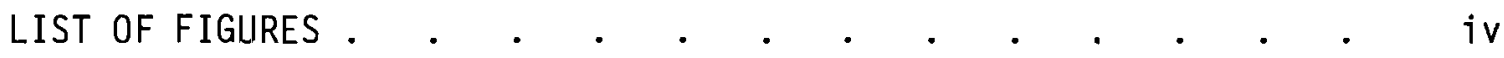

LIST OF TABLES

SUMMARY .

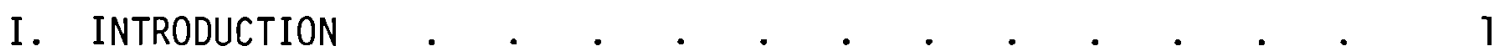

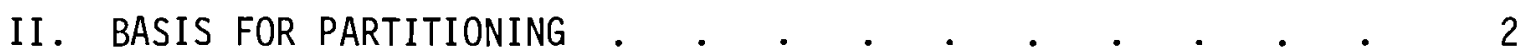

II . HANFORD PUREX PROCESS ACIDIC HIGH-LEVEL WASTE • • • • • 3

IV. NONRADIOCHEMICAL COMPOSITION OF HANFORD PUREX

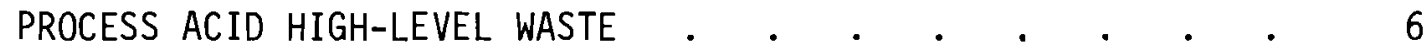

V. RADIOCHEMICAL COMPOSITION OF HANFORD PUREX

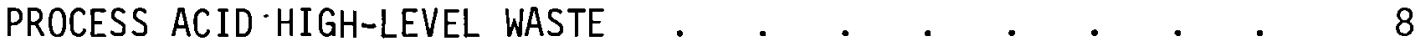

VI. SEPARATION FACTORS REQUIRED FOR PARTITIONING HANFORD PUREX PROCESS ACID HIGH-LEVEL WASTE . . . . . . 13

VII. PROCEDURES FOR SEPARATION OF ACTINIDE ELEMENTS FROM HANFORD PUREX PROCESS ACID HIGH-LEVEL WASTE • • • • • • 18

VIII. ESTIMATED COSTS OF PARTITIONING HANFORD PUREX PROCESS ACIDIC WASTES . . . . . . . . . . . . 30

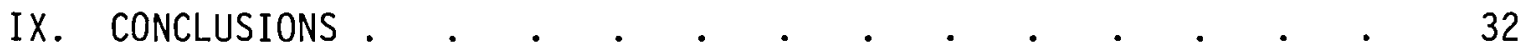

X. REFERENCES • • . . . . . . . . . . . . . 34 APPENDIX

BASES FOR ESTIMATING COSTS FOR PARTITIONING HANFORD

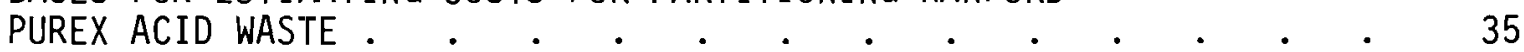

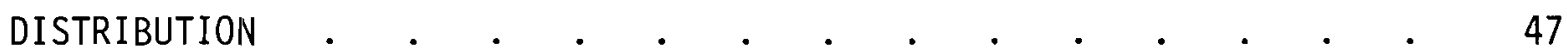




\section{LIST OF FIGURES}

1 Hanford Purex Process Schematic . . . . . . . . . 4

2 Growth of Am-241 in N-Reactor Fuel after Discharge . . . 10

3 Schematic of Hanford B-Plant Process when Treating Purex

Process Acid Waste (PAW). . . . . . . . . . 19

4 Schematic Flowsheet for Achieving $100 \mathrm{nCi} / \mathrm{g}$. . . . . 21

5 Plutonium Digestion and Partitioning for $10 \mathrm{nCi} / \mathrm{g}$ Case $\quad$. 28

6 Conceptual Flow Diagram Additions to B-Plant Feed

Preparation for Partitioning to 10 or $100 \mathrm{nCi} / \mathrm{g}$. . . . 36

7 Conceptual Flow Diagram Additional Solvent Extraction

System in B-Plant for Partitioning to 10 or $100 \mathrm{nCi} / \mathrm{g} \quad$. $\quad 37$

8 Conceptual Flow Diagram Additional Systems Needed for Purex Process for Partitioning to $10 \mathrm{nCi} / \mathrm{g} . . .+. .38$ 


\section{$\underline{\text { LIST OF TABLES }}$}

I Nonradiochemical Composition of Hanford Purex Process

Acid Waste (PAW). . . . . . . . . . . . 7

II Uranium and Transuranium Radionuclides Present in N-Reactor

Fuel Waste at Processing Time - Calculated Values . . . 11

III Concentrations of Long-Lived Fission Products in

$\mathrm{N}$-Reactor Fuel Waste--Calculated Values . . . . . . 12

IV Actinide Element Content of High-Level Waste at 1,000 Years . 16

$\checkmark$ Actinide Element Separation Factors Required for Hanford Purex Waste . . . . . . . . . . 17

VI Summary of Cost Estimates for Partitioning Hanford Purex Acid Waste . . . . . . . . . . . . 31

VII New Cell Space Requirements for Partitioning Hanford Purex Process Acid Waste . . . . . . . . 39

VIII Cost Estimate for Building and Cell Facilities . . . . 40

IX Summary of Process Equipment Costs . • . . . . . . 41

$X$ Equipment Costs $100 \mathrm{nci} / \mathrm{g}$ Case $. \quad . \quad . \quad . \quad . \quad . \quad . \quad . \quad 43$

XI Equipment Costs $10 \mathrm{nCi} / \mathrm{g}$ Case $. \quad . \quad . \quad . \quad . \quad . \quad . \quad . \quad 44$

XI Equipment Costs $1 \mathrm{nCi} / \mathrm{g}$ Case . . . . . . . . . . . . . 45

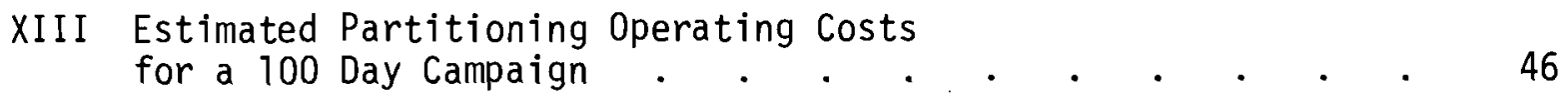




\section{SUMMARY}

A study was made of the technical and economic feasibility of applying the concept of partitioning to Hanford Purex process acidic high-level waste. Partitioning, as used here, means separating from the bulk waste a fraction containing long-1ived (>100 years, half-1ife) radionuclides. The residual bulk waste would then decay to a low radiological toxicity in a relatively short time - short enough to be within man's ability to exercise controlled storage. The long-lived fraction might then be disposed of by some special means such as transmutation, extraterrestrial transport or special storage.

The long-lived radionuclides in high-level waste are largely isotopes of the actinide elements. Other partitioning studies $(2,3,4)$ have emphasized separating the actinide elements from the waste. Removal of the actinide elements was emphasized in this study as in other partitioning studies.

Hanford Purex process acidic high-level waste will be produced again when the Purex plant is operated to process the inventory of irradiated $\mathrm{N}$-Reactor fuel. The total volume of such waste which might be produced is small - probably not over one million gallons. This may be compared to the tens of millions of gallons of alkaline high-level waste already in storage at Hanford.

Irradiated $\mathrm{N}$-Reactor fuel has a low integrated exposure ( $1500 \mathrm{MWD} / \mathrm{MT}$ ). In consequence, actinide element levels are relatively low in the high-level waste generated in processing the $\mathrm{N}$-Reactor fuels and relatively low separation factors are required to achieve the actinide element concentrations in the short-lived fraction which were considered in this study.

The most prominent actinide element radionuclide expected in the $\mathrm{N}$-Reactor fuel waste is $\mathrm{Am}-241$. This results from the relatively long (up to 4-5 years) cooling period the fuel will have before it is processed and because most of the plutonium, uranium and neptunium are removed in the processing. In-growth of $\mathrm{Am}-241$ from the $\mathrm{Pu}-241$ present in the fuel accounts for the prominence of Am-241. 


\section{viij}

The technology of high-level waste disposal is not far enough advanced to permit defining exactly the degree to which the long-1ived nuclides must be removed from the short-lived fraction to achieve partitioning objectives. Accordingly, a parametric study involving a series of residual actinide element concentrations in the short-lived waste fraction was made. These concentrations ranged from $1 \mathrm{nC} i$ to $10^{4} \mathrm{nCi}$ per gram of solidified waste. The lowest concentration would result in a short-1ived fraction which, after about 1,000 years deday, would present no more radiological risk to man than the natural radioactivity in the environment. The higher concentrations are involved in a philosophy of disposing the short-lived fraction in a site far removed from the biosphere where low release rates, dilution and retention of radionuclides by the surrounding media reduce the risk to man to acceptable levels.

Achieving even the lowest of these actinide element concentrations in the short-lived waste fraction appears technically feasible within existing separations technology. Demonstration of the technology on actual Hanford Purex process high-level waste is needed to confirm the feasibility, particularly for the lower actinide element concentrations considered. This is partially because the technology has not been applied on a plant scale basis to attain these low actinide element concentrations. Also, further knowledge of the composition of solids always present in such wastes is required to determine if the procedures suggested for treating them will adequately remove the actinide elements.

Flowsheets were developed which are based on existing technology and which are considered to have good probability of achieving the required actinide element separations. Actinide element concentrations expected in Hanford Purex process high-level waste, when processing $\mathrm{N}$-Reactor fuels, are less than $10^{4}{ }_{n} \mathrm{C} i / g$ of solidified waste. No removal of actinide elements is needed for this case. At $10^{3} \mathrm{nCi} / \mathrm{g}$, only $\mathrm{Am}-241$ is of concern and the Am separation currently achieved in Hanford B-plant operations is probably adequate. At $100 \mathrm{nCi} / \mathrm{g}$ some further removal of $\mathrm{Pu}$ is also required and some new processing facilities in the B-plant are proposed. At 10 and $1 \mathrm{nCi} / \mathrm{g}$, new processing facilities in both the Hanford Purex plant and the B-plant would be required. 
Preliminary cost estimates were made for implementing these separations schemes into the Hanford Purex plant and B-plant complex. These estimates covered incremental structure costs, new process equipment costs and operating costs based on an assumed processing schedule.

Where significant new processing facilities are proposed, the unit cost or cost for partitioning the waste from processing one ton of $\mathrm{N}$ Reactor fuel is relatively high because the assumed useful life of the facilities is short and the total amount of waste which would be processed in these facilities is low. The estimated costs (1974 dollars) were zero at $10^{4} \mathrm{nCi} / \mathrm{g}, \sim \$ 4 / \mathrm{MT}$ of waste processed at $10^{3} \mathrm{nCi} / \mathrm{g}, \sim \$ 1,400 / \mathrm{MT}$ at 100 $n \mathrm{Ci} / \mathrm{g}, \leadsto 33,900 / \mathrm{MT}$ at $10 \mathrm{nCi} / \mathrm{g}$ and $\$ 4,200 / \mathrm{MT}$ at $1 \mathrm{nCi} / \mathrm{MT}$. These are very rough estimates, and are undoubtedly already significantly low due to cost escalation. Additional costs due to increased volumes of short-lived waste which would have to be processed in the B-plant were not estimated. They are expected to be low.

The projected costs are significantly lower than costs estimated for partitioning commercial power reactor fuel wastes (2) partly because existing facilities at Hanford were used to the extent possible but also because the actinide element separation factors required are much lower for the Hanford Purex plant high-level waste.

The study concerned a particular high-level acidic waste which will result from the reprocessing of fuels having a much lower integrated exposure than is common for commercial power reactor fuels. The conclusions reached in this study were strongly influenced by the irradiation level of the fuels, the particular process which will be used to reprocess them, the fact that some facilities useful in partitioning already exist at the site and the relatively small amount of the waste which might be partitioned. Any extrapolation of the results of this study to the partitioning of commercial power reactor fuel waste must take these factors into account.

However, several factors such as the actinide separation technology involved, the concern about solids present in high-level wastes and the desire to minimize production of additional wastes which may be difficult to solidify and store are also applicable to studies of partitioning 
commercial high-level wastes. Hence, the approach to the problem and some of the technical reasoning may well be applicable to commercial waste partitioning studies. 
TECHNICAL AND ECONOMIC FEASIBILITY OF PARTITIONING HANFORD PUREX PROCESS ACID WASTE

\section{INTRODUCTION}

This report summarizes a study on the technical and economic feasibility of applying the concept of partitioning (removal of long-lived radionuclides, primarily actinides) to Hanford Purex process acidic high level radioactive waste. It discusses the amount and composition of such waste which may be produced, the actinide element separation factors required to attain given concentrations of actinide elements in the short-lived residual waste and separations schemes (based on existing separations technology) which have potential for achieving the desired removal of actinide elements. It also provides preliminary cost estimates for implementing the various separations schemes in the Hanford Separations - Waste Management complex.

The concept of partitioning as an approach to long-range management of high-level radioactive waste from reprocessing power reactor fuels has been studied in some depth in connection with the Advanced Waste Management Study conducted at BNW during the past two years. (1) A study to assess the technical and economic feasibility of partitioning high-level waste from commercial fuel reprocessing plants was made. (2) Various alternatives for managing the long-lived fraction (transmutation, extraterrestrial disposal, special storage and disposal) were evaluated in the Advanced Waste Management Study, as were risk analysis techniques toward determining the partitioning separation required. Extensive use was made of the information developed in these studies in developing partitioning requirements and separations schemes in the present study. Also, partitioning studies are in progress at Holifield National Laboratory (formerly ORNL), ${ }^{(3,4)}$ at Atlantic Richfield Hanford Company, and at Allied Chemical, Idaho. Full cognizance of the progress in these studies was maintained and use of the data was made where possible. 


\section{BASIS FOR PARTITIONING}

High-level radioactive waste generated in the reprocessing of irradiated nuclear fuels contains radionuclides having a wide range of half-lives from less than 100 days to millions of years. Present and past practice has been to treat the high-level waste as a single entity through storage, solidification and perhaps ultimate disposal.

An alternative approach in manaing high-level radioactive waste involves separating the total waste into fractions of different half 1 ives. Short-lived fractions would then decay to become radioactively nontoxic in relatively short times - times short enough to be within man's demonstrated ability to control the waste storage. Long-lived fractions, significantly reduced in mass, volume and radioactive decay heat output could be considered for other treatment, e.g., transmutation to nonradioactive or short-lived nuclides, extraterrestrial disposal or special terrestrial disposal.

Long-1ived radionuclides present in the wastes from processing irradiated nuclear fuels are primarily actinide elements and, to a much lesser extent, a few fission products. Thus, partitioning studies have emphasized separation of actinide elements from the short-lived waste fraction. Actinide element removal was emphasized in this study also.

At Hanford, high-level waste has routinely been made alkaline and stored in large underground tanks. More recently, the high-level waste from the Purex plant has been treated to remove cesium and strontium and encapsulate them for special storage. The remaining waste will be stored as an alkaline slurry until radioactive decay has reduced the heat evolution rate to a low level. Similarly, previously stored Purex process wastes are being treated to remove cesium and strontium and the remaining waste is stored as an alkaline slurry. All of the wastes at Hanford which are stored as alkaline slurries, including the Purex process waste from which cesium and strontium have been removed, are being concentrated and returned to the underground storage tanks with the objective of producing hydrated crystalline solids in the tanks. The mobility of the waste in the event of a tank failure will thus be greatly reduced. 
The present study considers the feasibility of applying the concept of partitioning to Hanford Purex process high-level waste, specifically to the waste before it is made alkaline with sodium hydroxide and thereby diluted with a large amount of sodium salts.

\section{HANFORD PUREX PROCESS ACIDIC HIGH-LEVEL WASTE}

The Hanford Purex plant is not now in operation, and it has not operated for the past several years. Hence, there is presently no Purex process acid high-level waste at Hanford. Waste which was produced immediately prior to the Purex plant shutdown was processed through B-plant for Cs and Sr removal and then made alkaline for storage. Purex process acid high-level waste will again be produced at Hanford when the Purex plant is operated to process the inventory of $\mathrm{N}$-Reactor fuels accumulated since the plant was shut down. There is no firm schedule available for operation of the Hanford Purex plant.

The greatly simplified Hanford Purex process flow diagram shown in Figure 1 indicates the path of aqueous waste in the plant. It shows that aqueous waste, other than cladding removal, metathesis and solvent recovery wastes all find their way to the high-level waste stream.

To provide a better understanding of the origin of some of the chemicals present in Hanford Purex process acidic high-level radioactive waste when processing $\mathrm{N}$-Reactor fuels, a brief description of the process will be given. The zircaloy cladding is removed (generally not completely) from the metallic uranium fuel elements by dissolution in $\mathrm{NH}_{4} \mathrm{~F}-\mathrm{NH}_{4} \mathrm{NO}_{3}$ solution (the Zirflex process). During this operation a small amount of uranium also reacts to form UF $_{4}$ which is sparingly soluble in the decladding solution. After the decladding solution is removed, the solid $\mathrm{UF}_{4}$ is metathesized to solid $\mathrm{U}(\mathrm{OH})_{4}$ with potassium hydroxide solution to separate uranium from the fluoride and thus minimize the amount of fluoride which accompanies the dissolved fuel into the separations processes. 




FIGURE 1. Hanford Purex Process Schematic 
Even with the metathesis step and practical rinsing of the decladding solution from the dissolver, some fluoride ion and some zirconium remain in the dissolver. The uranium metal fuel and the $\mathrm{U}(\mathrm{OH})_{4}$ are then dissolved in $\mathrm{HNO}_{3}$ solution. To protect the 304 stainless-steel dissolver from excessive corrosion due to the fluoride ion present, aluminum ion, as $\mathrm{Al}\left(\mathrm{NO}_{3}\right)_{3}$, is added to complex the fluoride ion. Because of these head-end operations, the dissolver solution contains an appreciable amount of fluoride, aluminum and zirconium which ultimately appear in the high-level waste.

In the first solvent extraction column, essentially all of the uranium and plutonium and about 90 percent of the neptunium are extracted and thus removed from the high-level acidic waste. Sodium nitrite solution is added near the bottom of this column to promote neptunium extraction. This is a source of sodium ion present in the high-level waste.

Extracted plutonium is separated from uranium and neptunium in a second column. In this column, the organic from the first column is contacted with dilute $\mathrm{HNO}_{3}$ solution containing ferrous sulfamate and sulfamic acid. Plutonium is reduced to poorly extracted $P$ U(III) and goes to the aqueous phase. Stripping uranium and neptunium from the extractant with dilute $\mathrm{HNO}_{3}$ in a third column completes the first cycle.

Uranium, plutonium and neptunium are further purified in subsequent solvent extraction cycles. Process chemicals added include sodium nitrite for oxidation of $\mathrm{Pu}$ (III) to extractable $\mathrm{Pu}$ (IV) and ferrous sulfamate to reduce neptunium to extractable $\mathrm{Np}$ (IV). The aqueous waste streams from all of these operations are concentrated and routed back to the first solvent extraction cycle via the neptunium recovery system or directly. Hence, process chemicals present in them; iron, sodium and sulfate (from sulfamate) eventually find their way to the high-level waste.

The aqueous waste from the first-cycle extraction column (which also contains the recycled wastes and is known as HAW) is concentrated by a factor of about eight to produce a stream called IWW. Nitric acid removed in this operation is recovered for reuse. To reduce the amount of acid to be neutralized by $\mathrm{NaOH}$, the nitric acid concentration in the IWW is then reduced to about one molar by denitration with sugar to produce the Purex 
acid waste (PAW). This is the Purex process high-level acid waste which was used as the basis for this study. PAW is stored awaiting processing in the B-plant for removal of most of the Cs and Sr.

The flowsheet volume of Hanford Purex plant high-level acidic waste is about $210 \mathrm{gal} / \mathrm{MT}$ of $\mathrm{N}$-Reactor fuel processed. In the present waste management program, this waste will be treated for removal, encapsulation and separate storage of the Cs and Sr present; the residual waste will be made alkaline and stored in mild steel underground tanks for radioactive decay. Finally, the alkaline waste will be concentrated to a crystalline solid (salt cake; not a calcine) and returned to mild steel underground tanks for further storage. The volume which this crystalline waste will occupy is not precisely known at this time but it will almost certainly be less than $110 \mathrm{gal} / \mathrm{MT}$ of fuel processed. Thus, assuming a maximum of 4500 MT of N-Reactor fuel yet to be processed through the Hanford Purex plant, less than 500,000 gallons of alkaline salt cake will be produced as a result of processing this remaining inventory of $\mathrm{N}$-Reactor fuel. This is a very small amount compared to more than ten million gallons of alkaline salt cake which will be in storage in underground tanks after the present inventory of stored waste is concentrated to salt cake.

\section{NONRADIOCHEMICAL COMPOSITION OF HANFORD PUREX PROCESS}

\section{ACIDIC HIGH-LEVEL WASTE}

Table I (page 7) shows estimates of the nonradioactive chemical composition of high-level radioactive waste produced when $\mathrm{N}$-Reactor fuel is processed in the Hanford Purex plant. These are basically flowsheet values $^{(5)}$ and represent average expected composition of the waste. It must be remembered that waste composition is strongly influenced by process upsets, adjustments, etc., and that actual values will vary somewhat from those shown. The total concentrations are probably reasonably consistent from batch to batch with the exception of zirconium and fluoride which originate as carryover from a metathesis step and are thus poorly controlled. The listed fluoride concentration is taken from the flowsheet document but considerable variation occurs; plant data 
TABLE I. Nonradiochemical Composition of Hanford Purex Acid Waste (PAW)

$\begin{array}{lc} & \begin{array}{c}\text { Purex } \\ \text { Acid Waste }\end{array} \\ & 1.0 \\ \mathrm{Na} & 0.1 \\ \mathrm{Fe} & 0.08 \\ \mathrm{A1} & 0.72 \\ \mathrm{Cr} & 0.002 \\ \mathrm{Ni} & 0.002 \\ \mathrm{Zr} & 0.1 \\ \mathrm{NO}_{3} & 3.5 \\ \mathrm{SO}_{4} & 0.2 \\ \mathrm{PO}_{4} & 0.01 \\ \mathrm{~F} & 0.15\end{array}$


obtained during 1969 shows nearly a twenty-fold variation in fluoride concentration in eight batches of feed analyzed. No analytical data are available on the concentration of zirconium; the listed value of $0.1 \mathrm{M}$ represents a carryover of ten percent of the zirconium.

Concentrations of iron, chromium and nickel, introduced by corrosion of process equipment, are based on a corrosion rate of $3 \mathrm{mlls} / \mathrm{mo}$ in the waste acid concentrator. Phosphate concentration was estimated from a study by Van Tuy1. (6) The sulfate concentration shown assumes hydrolysis of all of the sulfamate added as ferrous sulfamate and sulfamic acid.

In the past, Purex acid waste has contained up to five volume percent solids. Process improvements led to a reduction in solids content to less than one volume percent. Under these conditions, the solids were composed largely of zirconium phosphate and silica, with less amounts of metal sulfates.

V. RADIOCHEMICAL COMPOSITION OF HAINFORD PUREX PROCESS HICAH-LEVEL WASTE

Irradiated $N$-Reactor fuel is presently being stored at Hanford awaiting eventual processing in the Hanford Purex plant. In this study it was assumed that the fuel will be processed in the same order that it was pushed from the reactor, i.e., oldest fuel first and proceeding to the youngest fuel at the end of the processing. It was also assumed in this study that processing the N-Reactor fuel will begin in mid-1976 and that the processing schedule (fuel reprocessing alternated with waste treatment on a campaign basis) will be such that 900 to 1300 MT of fuel will be processed per year. If the fuel is processed according to this schedule, it will have aged one to four years prior to processing. Based on past practice the N-Reactor fuel was assumed to have an average exposure of $1500 \mathrm{MWD} / \mathrm{MT}$ at $11 \mathrm{MW} / \mathrm{MT}$.

The ORNL ORIGEN Code ${ }^{(7)}$ was used to calculate the concentration of the significant actinide elements and long-lived fission product nuclides in the $\mathrm{N}$-Reactor fuel expected to be processed in the Hanford Purex plant. A fuel exposure of $1380 \mathrm{MWD} / \mathrm{T}$ (1520 MWD/MT) at $10 \mathrm{MW} / \mathrm{T}$ (11 MW/MT) was used for these calculations. Plutonium and uranium losses to the high-level 
waste were assumed to be 0.1 percent and neptunium loss was taken as ten percent. It is recognized that, in other waste management studies, loss of uranium and plutonium to the high-level waste is generally assumed to be 0.5 percent and that essentially al1 of the neptunium is considered present in the waste. However, 99.9 percent recovery of $U$ and $P u$ has been obtained routinely during processing of production fuels in the Hanford Purex plant. Also, high neptunium recovery is normal in Hanford Purex plant operation; loss of about ten percent of the neptunium to the high-level waste is usual.

The relatively long time before processing was also considered in calculating the radionuclide content at processing time, i.e., the ingrowth of daughters was considered. The major effect of the processing schedule on partitioning is the growth of Am-241 and its daughter Np-237 from the decay of $\mathrm{Pu}-241$ according to the sequence

$$
{ }^{241} \mathrm{Pu} \underset{13.2 \mathrm{y}}{\longrightarrow}{ }^{24.1} \mathrm{Am} \frac{\alpha}{458 \mathrm{y}} \rightarrow{ }^{237} \mathrm{~Np} \text {. }
$$

Figure 2 shows the growth of Am-241 into the fuel from Pu-241 as a function of cooling time. The amount of Am-241 present varies from about one $\mu \mathrm{C} i / T$ to about $10 \mu \mathrm{C} / \mathrm{T}$ of irradiated $\mathrm{N}$-Reactor fuel as the age varies from 90 days to 4.5 years. An average value of $5 \mu \mathrm{C} i / T$ was used for further considerations in this study.

Table III shows calculated values of activity for various uranium and transuranium nuclides in irradiated $N$-Reactor fuel at separation time. These values are average values for separation times ranging from 90 days to 4.5 years and they assume losses of 0.1 percent of the $U$ and $\mathrm{Pu}$ and 10 percent of the $\mathrm{Np}$ to the waste. The most significant at processing time are Am-241 and $\mathrm{Cm}-242$. The latter, because of its relatively short half-1 ife (163 days), decreases rapidly with time.

Calculated activity levels of long-lived fission product nuclides in irradiated $\mathrm{N}$-Reactor fuel are shown in Table IV. At separation time, Cs-137 and $S r-Y-90$ and $S m-151$ are far more prevalent than other 1ong-1ived isotopes. Because of their relatively short half-1ives, Cs-137 and Sr-Y-90 decay to 
TABLE III. Concentrations of Long-Lived Fission Products in $\mathrm{N}$-Reactor Fuel Waste--Calculated Values

\begin{tabular}{|c|c|c|}
\hline Nucl ide & $\begin{array}{l}\mathrm{Ci} / \mathrm{MT} \\
\text { at Separation } \\
\end{array}$ & $\begin{array}{l}\mathrm{Ci} / \mathrm{MT} \\
\text { at } 10^{3} \text { Years } \\
\end{array}$ \\
\hline Se-79 & $2.0 \times 10^{7}$ & $1.9 \times 10^{7}$ \\
\hline $\mathrm{Rb}-87$ & $1.1 \times 10^{3}$ & $1.1 \times 10^{3}$ \\
\hline$S r-Y-90$ & $8.6 \times 10^{12}$ & $1.7 \times 10^{2}$ \\
\hline $\mathrm{Zr}-93$ & $9.6 \times 10^{7}$ & $9.6 \times 10^{7}$ \\
\hline $\mathrm{Nb}-93 \mathrm{~m}$ & $3.6 \times 10^{6}$ & $9.6 \times 10^{7}$ \\
\hline Tc-99 & $7.0 \times 10^{8}$ & $7.0 \times 10^{8}$ \\
\hline $\mathrm{Pd}-107$ & $2.5 \times 10^{6}$ & $2.5 \times 10^{6}$ \\
\hline $5 n-126$ & $1.6 \times 10^{7}$ & $1.6 \times 10^{7}$ \\
\hline$S b-126 m$ & $1.6 \times 10^{7}$ & $1.6 \times 10^{7}$ \\
\hline$S b-126$ & $1.6 \times 10^{7}$ & $1.6 \times 10^{7}$ \\
\hline Cs-135 & $1.1 \times 10^{7}$ & $1.1 \times 10^{7}$ \\
\hline$C s-137$ & $5.0 \times 10^{12}$ & $4.6 \times 10^{2}$ \\
\hline$S m-151$ & $1.2 \times 10^{11}$ & $4.2 \times 10^{7}$ \\
\hline
\end{tabular}


relatively low levels in 1,000 years. Sm-151 is still relatively abundant at 1,000 years but continues to decrease relatively rapidly because of its intermediate half-life and in an additional 1,000 years would decay to a relatively low level. The remaining isotopes listed have very long halflives and will decrease in activity very slowly with time.

\section{SEPARATION FACTORS REQUIRED FOR PARTITIONING HANFORD PUREX PROCESS ACID HIGH-LEVEL WASTE}

The objective in partitioning high-level radioactive wastes is to provide a safer and more economical long-term high-level waste management option through separation of the waste into a long-lived and a shortlived fraction. The short-lived fraction would then decay in a time period short enough to be considered practical for controlled storage (say 1,000 years) to a radioactive level which represents no significant radiological risk to man when released directly to the biosphere or when disposed of in one of the several disposal techniques presently under study.

At the present time, there is inadequate information available for a basis on which to decide to what extent the long-lived isotopes must be removed from the short-lived isotopes in order to accomplish this objective. Further pathway analyses and risk calculations are needed to establish these requirements. One approach assumes that the high-level waste is converted to a solid and that the solid will decay to negligible toxicity to man in about 1,000 years. This requires that the long-lived actinide element content of the short-lived waste fraction be one to ten ${ }_{n} \mathrm{C} i$ of activity per gram of solid. Another approach is to assume that the solidified short-1ived waste fraction wil1, after 500-1,000 years, contain long-lived nuclides such that the calculated hazard index will be comparable to that of naturally occurring uranium ores. Other approaches, as studied in Advanced Waste Management Studies (1) assume ultimate disposal of the short-lived waste fraction in some terrestrial location such as in an ice sheet, a deep sea trench, a salt dome or a basalt cavern and attempt to determine the risk to man of the waste escaping the disposal site and 
migrating to man's environment. Dilution by water, retention by soils and slow release rates decrease the risk to man. The extent to which these various pathways to man's environment reduce the risk to man due to long-lived nuclides is not yet completely evaluated. Therefore, permissible concentrations of long-lived isotopes in the short-lived waste fraction cannot be defined. Some studies indicate this reduction in risk may be several orders of magnitude.

Since no single concentration of long-lived isotopes in the short-lived waste fraction can be defined at present to fit the various waste disposal concepts being evaluated, a series of concentrations was considered in this study. The lowest concentration considered was one $\mathrm{nCi} / \mathrm{g}$ of the waste when converted to a calcined solid. Other concentrations considered were 10 , 100,1000 and $510^{4} \mathrm{nCi} / \mathrm{g}$. At one $\mathrm{nCi} / \mathrm{g}$ the solid waste would represent about the same risk to man as the naturally occurring radioactivity in man's normal surroundings. The $10 \mathrm{nC} i / \mathrm{g}$ is the currently accepted level for alpha emitting isotopes in contaminated solid wastes for long-term storage in near surface facilities. At $1,000 \mathrm{nCi} / \mathrm{g}$ the solid waste would, after decay of the short lived isotopes, represent about the same hazard to man as naturally occurring radioactive minerals such as pitchblende. A concentration of $10^{4} \mathrm{nCi} / \mathrm{g}$ may represent an insignificant hazard to man if the waste is disposed of in a site far removed from man's environment and allowance is made for retention and dilution if the waste escapes and returns to man's environment.

The mass of solidified high-level waste per ton of fuel processed in the Hanford Purex plant cannot be precisely stated. The composition of the waste will vary with plant operating conditions. Also, the amount of solid would depend on whether the waste was simply calcined or converted to a glassy solid by adding glass formers and melting the mixture. For this study it was assumed that the mass of solidified high-level waste per ton of fuel processed would be about $140 \mathrm{~kg} / \mathrm{MT}$. This corresponds reasonably well with the expected mass of the solidified waste if it is simply calcined to oxides. If the waste were converted to a glass, the weight per MT might be two to three times as great. 
Table IV shows actinide element activity which would be present in Hanford Purex process acid waste 1,000 years after processing. Also shown are similar data for high-level waste expected from commercial processing of Diablo Canyon Reactor fuel. (7) The latter data are shown here to emphasize the much higher actinide element content expected from power reactor fuels which have much higher integrated exposure. Actinide separation factors (SF) required to attain comparable residual concentrations of actinide elements in the short-lived waste fraction are typically about 100 times greater for the power reactor fuel waste than for the Hanford Purex process waste.

Table $V$ shows the actinide element separation factors required to reduce the actinide element content of Hanford Purex process acid waste to the various levels described above. These calculated separation factors are based on $140 \mathrm{Kg} / \mathrm{MT}$ of solid waste per ton of fuel processed, on the assumption that partitioning of the actinide elements is done at the time the $\mathrm{N}$-Reactor fuels are processed and on the assumption that the waste is aged an additional 1,000 years following processing. That is, they are the actinide element separation factors that would be required at fuel processing time to produce a short-lived waste fraction which would, after 1,000 years decay, have the actinide element activity concentrations shown.

Partitioning during or immediately after fuel processing is the only alternative considered in this study. [Without significant additiona] storage capacity for acidic high-level wastes, there is only limited capacity for long-term storage of acidic waste at Hanford.]

It is apparent from Table $V$ that no treatment of the waste is required for actinide element activity concentrations of $10^{4} \mathrm{nCi} / \mathrm{g}$ of solidified waste. At $10^{3} \mathrm{nCi} / \mathrm{g}$, only americium is of concern. A separation factor of about six is all that is needed. At 100 and $10 \mathrm{nCi} / \mathrm{g}$, both plutonium and americium are of concern and at $1 \mathrm{Ci} / \mathrm{g}$, uranium, neptunium, plutonium and americium are all of concern although the separation factors required are relatively small. 
TABLE IV. Actinide Element Content of High-Level Waste at 1,000 Years

$n C i / M T$ of Fuel

\begin{tabular}{ll}
$\begin{array}{c}\text { Hanford Purex } \\
\text { Waste }\end{array}$ & $\begin{array}{c}\text { Diablo Canyon } \\
\text { Waste }\end{array}$ \\
\hline $8.3 \times 10^{5}$ & $4.5 \times 10^{7}$ \\
$8.3 \times 10^{5}$ & $1.7 \times 10^{10}$ \\
$1.1 \times 10^{8}$ & $1 \times 10^{10}$ \\
$1.1 \times 10^{9}$ & $5.7 \times 10^{10}$ \\
$1.1 \times 10^{5}$ & $2.5 \times 10^{7}$
\end{tabular}

a. Includes $10 \%$ of the $\mathrm{Np}$ and $0.1 \%$ of the $\mathrm{U}$ and $\mathrm{Pu}$.

b. Includes $100 \%$ of the $\mathrm{Np}$ and $0.5 \%$ of the $U$ and $\mathrm{Pu}$. 
TABLE V. Actinide Element Separation Factors Required for Hanford Purex Waste

Actinide Element Separation Factor to Attain Stated Residual Level in Solidified Waste After 1,000 years Storage (a).

Element

$\underline{\mathrm{nCi} / \mathrm{g}}^{(\mathrm{b})} \quad \underline{\mathrm{nCi} / \mathrm{g}}^{(\mathrm{b})} \quad \underline{100 \mathrm{nCi} / \mathrm{g}^{(b)}} \quad \underline{1000 \mathrm{nCi} / \mathrm{g}}{ }^{(\mathrm{b})} \quad{\underline{10^{4} \mathrm{nCi} / \mathrm{g}}}^{(\mathrm{b})}$

U

6
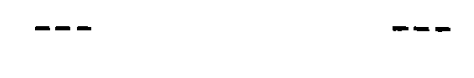

$\mathrm{Np} \quad 6$

$\mathrm{Pu} \quad 800$

8000

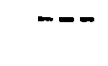

80

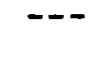

Am

800

8

80

$\mathrm{Cm}$

-.-

$---$

$---$

--
--

--

---

a. Based on $140 \mathrm{~kg}$ of solidified waste per ton of fuel processed.

b. Average values for the processing schedule shown in Figure 1. Includes activities from daughter elements. Based on $0.1 \% \mathrm{U}$ and Pu 1 oss and $10 \% \mathrm{~Np}$ loss. 
VII. PROCEDURES FOR SEPARATION OF ACTINIDE ELEMENTS FROM

HANFORD PUREX PROCESS HIGH-LEVEL WASTE

This section will describe proposed separation schemes to attain the actinide element separation factors on Hanford Purex process acidic waste required to attain the residual actinide element concentrations listed in Table V.

Activity Level of About $10^{4} \mathrm{nCi} / \mathrm{g}$ of Solidified Waste

No further treatment of the waste is required for concentrations of actinide elements equal to or greater than about $10^{4} \mathrm{nCi} / \mathrm{g}$ of solidified waste.

Case 1 - Activity Level of About $10^{3} \mathrm{nCi} / \mathrm{g}$ of Solidified Waste

Only americium is of concern at $10^{3} \mathrm{nCi} / \mathrm{g}$ of solidified waste. The required separation factor for americium is about 8 . It is proposed that no additional processing is required beyond that now done in the Hanford B-plant solvent extraction system for removal of strontium from the waste. A schematic of the waste treatment process in the Hanford B-plant is shown in Figure 3. The ICP stream in this process contains about 80 percent of the americium which enters the solvent extraction system in the Purex process acid waste. This stream could be treated separately for concentration and storage rather than recombined with the first column raffinate as is currently done.

It is recognized that this stream also contains most of the rare earth elements. No further processing of this stream to separate americium from the rare earth elements was considered in this study since required purity of the americium is not defined. Technology for the purification of americium in this stream by ion exchange chromatography is available. (8) In the absence of a need to recover the americium for use, the B-plant ICP stream could be concentrated and stored separately. Additional processing to separate the lanthanide elements from the americium would depend on later decisions regarding ultimate disposal of the americium.

Case 2 - Actinide Element Level About $100 \mathrm{nCi} / \mathrm{g}$ of Solidified Waste

To reduce the actinide element content of Hanford Purex process waste to a level of about $100 \mathrm{nCi} / \mathrm{g}$ of solidified waste would require separation 

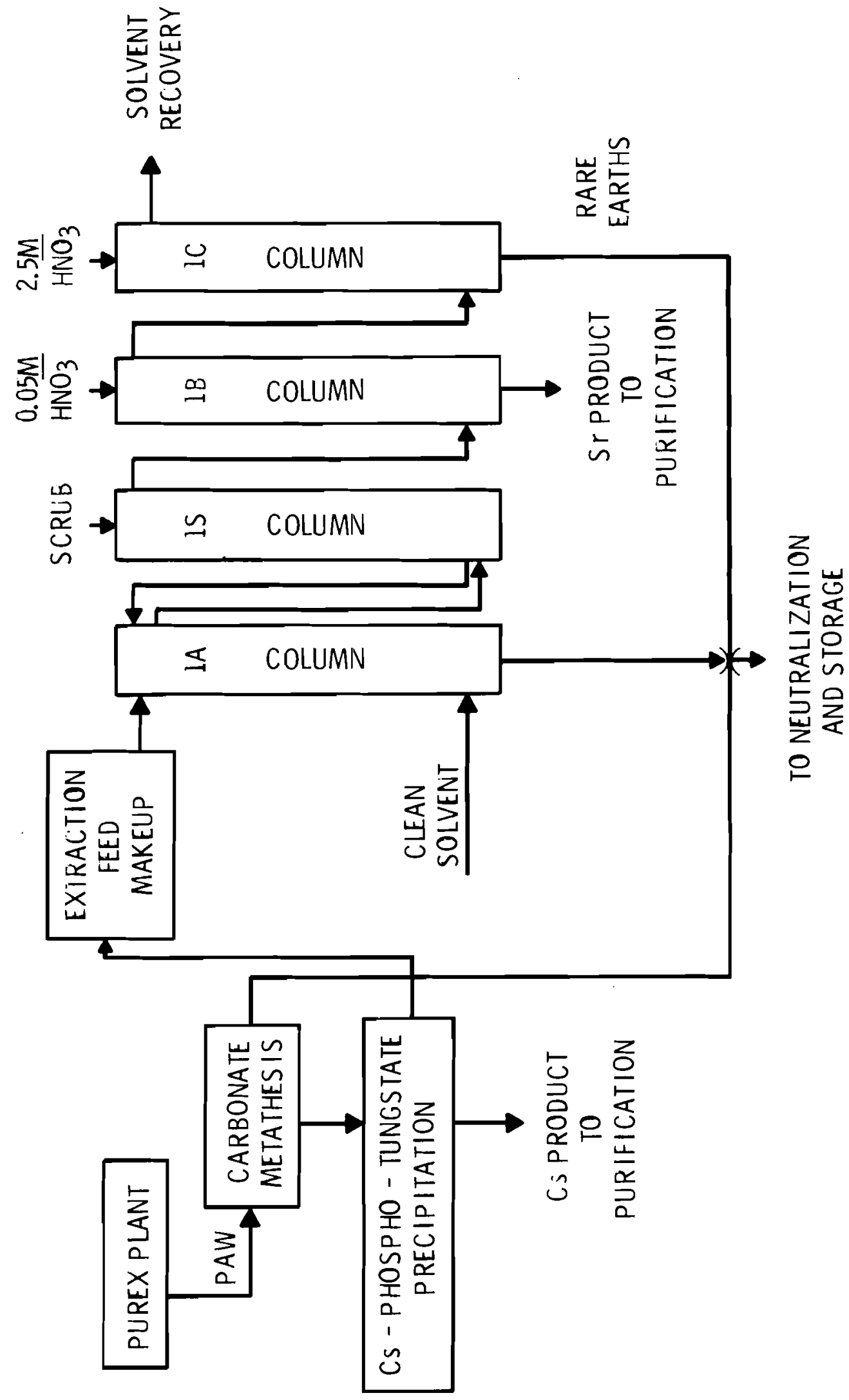
factors of about 8 and 80 for $\mathrm{Pu}$ and Am, respectively. These factors are based on an assumed loss of 0.1 percent of the Pu present to the high-level waste. Measurements made during Purex plant operation indicate $\mathrm{Pu}$ losses as low as 0.02 percent. If such measured losses are actual and represent the total Pu present (extractable as well as inextractable) in the stream then no further Pu removal would be required to approach a $100 \mathrm{nCi} / \mathrm{g}$ level in solidified high-level waste. If the assumed 0.1 percent $\mathrm{Pu}$ loss is actual, it is probable that most of this $\mathrm{Pu}$ is present in the waste as solids or as inextractable species.

The flowsheet proposed for this case is shown in Figure 4. The solids present in PAW are segregated and rinsed and then treated with mixed hydroxide-carbonate solution to convert the sulfate and phosphate precipitates to hydroxides and carbonates. The hydroxide-carbonate precipitate is dissolved in $\mathrm{HNO}_{3}$ and recombined with the PAW. (All of these operations are currently performed in the Hanford B-plant.) To obtain the required separation to reach the $100 \mathrm{nCi} / \mathrm{g}$ goal, a solvent extraction cycle is added to extract the actinide elements from the combined PAW and dissolved precipitate solutions before the waste is treated in the B-plant to remove the Cs and $\mathrm{Sr}$. No provision is made for conversion of soluble but inextractable $\mathrm{Pu}$ species to extractable species. It was assumed that the amount of such species is so small that attaining the separations goal can be accomplished without removing solids.

Ion exchange and solvent extraction were both considered as potential separations techniques to attain the required separation of Am and $\mathrm{Pu}$ from the high-level waste. While both techniques will potentially provide the needed separation, the large trivalent cation element content of the waste would require the use of very large exchanger beds and very large volumes of eluting chemicals to attain the required separations by ion exchange. Consequently, solvent extraction procedures were considered the more practical of the two techniques and were used throughout this study. 




FIGURE 4. Schematic Flowsheet for Achieving $100 \mathrm{nCi} / \mathrm{g}$ 
Additional partitioning of Am can be obtained by segregating and processing the B-plant ICP stream as proposed for the $1000 \mathrm{nCi} / \mathrm{g}$ case if this is required for additional americium separation.

The flowsheet shown in Figure 4 specifies 50 percent tributyl phosphate (TBP) in a hydrocarbon diluent such as NPH (normal paraffin hydrocarbon) as the extractant. Use of more dilute dibutyl butyl phosphonate (DBBP) would give equally good, if not better, actinide element partitioning but would give less decontamination from zirconium unless multiple columns were used to sequentially strip the americium (plus rare earth elements), zirconium and plutonium as proposed by Schulz and Richardson. (10)

The flowsheet employs monoban [monobasic aluminum nitrate, $A 1(\mathrm{OH})$ $\left.\left(\mathrm{NO}_{3}\right)_{2}\right]$ to lower the acidity of the PAW. Use of monoban instead of sodium hydroxide involves less likelihood of precipitate formation during acidity reduction and also increases the salting strength of the aqueous phase. Sodium nitrate is used in the scrub stream, rather than aluminum nitrate, to minimize the aluminum contamination in the americium product (the presence of aluminum in the americium product stream would complicate further purification of the americium by cation exchange if further purification is desired).

The extracted actinide elements and rare earth elements are co-stripped with dilute nitric acid and the resulting aqueous is concentrated for storage pending later decisions as to its ultimate disposal. The stripped extractant is recycled to the extraction column. A small fraction of the solvent is washed each cycle to prevent excessive buildup of solvent degradation products.

Aqueous raffinate from the extraction column (which represents the short-lived fraction of the waste) is made slightly acid to minimize the likelihood that precipitates will form which might complicate subsequent cesium removal as cesium phosphotungstate in the B-plant operations.

The 50 percent TBP flowsheet shown in Figure 4 would provide little separation of the actinide elements from ruthenium and the rare earth elements. $(8,11)$ It is likely that decontamination from zirconium will 
be very sensitive to process conditions, Americium extracted from Hanford Redox process wastes was decontaminated quite well from zirconium but most of the zirconium was apparently carried on solids from which zirconium was not extracted. (9) Americium extracted from waste produced in processing $\mathrm{Pu}$ - Al alloy fuel elements was decontaminated from zirconium by factors of only 10-30. (11)

Adding this partitioning solvent extraction cycle to the present Hanford high-level waste treatment system would increase the volume of solution to be treated for cesium removal by a factor of about 1.6. This should pose no serious problem. The proposed partitioning cycle would also increase the amount of aluminum present in the waste by a factor of about 2.7 and would substantially increase chemical costs and solution volumes in the strontium removal portion of the B-plant; however, the aluminum might be an advantage if the waste were calcined and converted to a glass. The present B-plant equipment should be able to handle the throughput though a slightly reduced rate could be necessary.

Other flowsheets could be devised which do not increase the amount of aluminum in the waste, but they would involve the use of sodium hydroxide instead of monoban for $\mathrm{pH}$ adjustment. The probability of precipitate formation would be increased and, because these precipitates would likely include actinide elements, the potential for achieving the required actinide element separation would be decreased.

A solvent extraction cycle involving extraction of americium from more strongly acid, less highly salted solutions would allow actinide element partitioning to be accomplished without these perturbations to the subsequent waste treatment steps. Two such cycles have been the subject of recent investigations; however, both are preliminary in nature and were not used as the basis for partitioning in this study. Atlantic Richfield Hanford Company $(12)$ is investigating the use of dihexyl - N, N - diethylcarbamylmethylene phosphonate (DHDECMP) to extract americium from acidic reclamation facility wastes. Their initial results appear quite promising but some problems apparently remain to be resolved. Also, the effects of certain ions (e.g., $\mathrm{Zr}$ ) on partitioning, which are present in PAW but not in the reclamation waste, require study before the process could be considered for partitioning 
Purex process high-level waste. A recent paper ${ }^{(13)}$ reported very good extraction of americium from acidic solutions by an extractant prepared by reacting phosphorus pentoxide with di-2-ethylhexylphosphoric acid. No means of stripping the americium from the extractant was reported, however.

Another potential cycle that is not in the realm of "established technology" involves coextraction of actinide elments, lanthanide elements and other fission products from highly acidic solution (13-15M $\mathrm{HNO}_{3}$ ) and subsequent separation of the various fractions by selective stripping procedures.

Additional equipment requirements not covered in the preceding discussion include provisions for routing the metathesis waste solution from the centrifuge to underground storage through a receiver other than the one used for the PAW supernate. If this is not done, the maximum attainable partitioning factor will be 1 imited by the amount of PAW left behind in the receiver when the metathesis waste passes through. In the current mode of B-plant operation, the metathesis waste solution (and PAW residue) is sent to a tank of neutralized waste for later rework, but this option is not a valid one for a process to partition acid waste.

Case 3 - Actinide Element Level About $10 \mathrm{nCi} / \mathrm{g}$ of Solidified Waste

Data in Table VI indicate that separation factors of about 80 for $\mathrm{Pu}$ and 800 for $\mathrm{Am}$ are required to attain about $10 \mathrm{nCi} / \mathrm{g}$ of actinide elements in the residual waste. It appears very likely that treatment of the waste to convert inextractable forms of plutonium to extractable forms wi 11 be required to attain this goal. In meeting this requirement it is necessary to consider technology which has not been used in plant practice. Such procedures have not been required in the past; also we do not know the nature or amount of inextractable species present in Hanford Purex process acid waste. The proposed flowsheet steps are felt to have a reasonable probability of success and are compatible with the Purex and B-plant processes. 
The Hanford Purex process high-level waste stream can be considered as passing through three different stages before it leaves the Purex plant. The first stage is the HAW solution which is the waste from the first solvent extraction column. The second stage is the TWW solution which is the bottoms from the TWW acid waste concentrator and which contains eight-fold higher concentrations of the non-volatile materials than does the HAW. The third stage is the PAW which is obtained by sugar denitration of the IWW solution. The concentrations of $\mathrm{HNO}_{3}$ and of aluminum (the major nonvolatile component) in these solutions are as follows: ${ }^{(4)}$

\begin{tabular}{|c|c|c|}
\hline \multirow[b]{2}{*}{ Solution } & \multicolumn{2}{|c|}{ Molarity } \\
\hline & $\mathrm{HNO}_{3}$ & A1 \\
\hline HAW & 3.0 & 0.085 \\
\hline $1 W W$ & 2.8 & 0.68 \\
\hline PAW & 0.95 & 0.68 \\
\hline
\end{tabular}

A partial listing of inextractable forms of $\mathrm{Pu}$ which could be present at various stages is:

- Soluble complexes with fluoride (present due to incomplete metathesis and rinsing after decladding), with oxalate formed during the sugar denitration of 1WW to PAW, with ligands formed by the reaction of $\mathrm{HNO}_{3}$ with uranium carbide (which is present as an impurity in the fuel elements) or with sulfate formed by hydrolysis of the sulfamate added in various valence control procedures.

- Solid compounds formed with the various complexing agents including precipitates of other metal ions which carry the plutonium compounds.

- Plutonium sorbed by such inorganic ion exchange materials as hydrous oxides of zirconium, tin and silicon. Hydrous oxides of zirconium can form during decladding unless the $\mathrm{pH}$ is kept low by removing the ammonia efficiently. Some of what does form may be carried to subsequent steps. Tin is present in the cladding and dissolves less rapidly than zirconium; hence, some tin may be left after decladding and become converted to stannic oxide during $\mathrm{HNO}_{3}$ 
dissolution of the fuel. Silicon is present in the fuel and also is probably introduced to the process as impurity in process chemicals.

- Plutonium polymers may be formed under transient localized conditions of low acidity in the dissolver or during denitration.

The relatively simple procedure thought to be most likely to produce a solution from which $\mathrm{Pu}$ can be efficiently extracted is to digest the HAW solution (after steam-stripping to remove the entrained and dissolved solvent). This procedure should dissolve solids, destroy the ligands formed by the reaction of $\mathrm{HNO}_{3}$ with uranium carbide and break up plutonium polymers. The digestion which normally takes place in the IWW concentrator should also accomplish these effects but in IWW there would be more chance of stable precipitate formation and greater sorption of $\mathrm{Pu}$ by inorganic ion exchange materials because of the eight-fold higher concentrations. Hence, digestion of HAW is preferred. Digestion of PAW suffers the same drawbacks as does digestion of IWW and the likely presence of oxalate adds yet another drawback.

The conversion to extractable forms of plutonium could be further facilitated by the addition of an oxidant to oxidize plutonium to the hexavalent form which is less likely to form complexes, polymers and precipitates than is the tetravalent form. Hexavalent plutonium is not as highly extractable as the tetravalent form, but it is sufficiently extractable that its separation should be no problem. The use of dichromate as the oxidant would require that the digester be constructed of titanium instead of $304 \mathrm{~L}$ stainless steel and also that the dichromate be reduced to $\mathrm{Cr}$ (III) before the waste is concentrated in the $304 \mathrm{~L}$ stainless-steel IWW concentrator to prevent excessive dichromate-caused corrosion of stainless-steel equipment. It would probably also be good practice to add additional aluminum to the HAW as further insurance against excessive fluoride-caused corrosion of a titanium vessel. Other common oxidants suffer from the drawbacks of adding corrosive halides to the solutions and/or oxidizing fission product ruthenium to volatile $\mathrm{RuO}_{4}$. 
The conceptual flowsheet developed for processing waste in the Purex plant to yield a plutonium separation factor of 50 (or more) is shown in Figure 5. The HAW is steam-stripped to remove the dissolved and entrained solvent and is then digested for several hours at $4 \mathrm{M} \mathrm{HNO}_{3}$ to convert the plutonium to extractable forms. A small concentration is also achieved in this step by boiling off enough water to effectively remove organics in the stripper tower. The digested feed is then sent to a 30 percent TBP-NPH extraction cycle for removal of the plutonium (uranium should also be removed effectively). Under the conditions shown here, four extraction stages should give a plutonium decontamination factor of about 100, and six extraction stages should give a factor of about 1000 if conversion of al1 the plutonium to extractable plutonium monomer was achieved in the digestion step. Dilute $\mathrm{HNO}_{3}$ scurbbing is employed to aid zirconium decontamination and to reduce the concentration of $\mathrm{HNO}_{3}$ in the organic product stream. The organic stream, containing recovered plutonium and uranium can be returned to the Purex plant $H A$ column or to the first cycle organic product without excessive perturbation of normal plant operation. Hence, special handling of the recovered $\mathrm{Pu}$ and $\mathrm{U}$ is not needed. The waste stream from this added cycle goes to the IWW concentrator and then to sugar denitration as in normal plant operation.

Plutonium which is not extracted from the digested HAW will still undergo processing in the B-plant solvent extraction system. In addition to the solids treatment and americium partitioning 50 percent TPB cycle discussed in the $100 \mathrm{nCi} / \mathrm{g}$ case, additional plutonium partitioning might be achieved in the B-plant strontium recovery solvent extraction cycle by reducing the $\mathrm{Pu}(\mathrm{IV})$ to $\mathrm{PU}(\mathrm{III})$ thus forcing it to follow americium to the B-plant ICP stream.

The americium decontamination factor of about 800 required to reach the $10 \mathrm{nCi} / \mathrm{g}$ level may be attainable using the same processes as used in the $100 \mathrm{nCi} / \mathrm{g}$ case (see conceptual flowsheet in Figure 3 ). More stages would be required in the partitioning solvent extraction cycle and/or more reliance would be placed on americium recovery in the B-plant solvent extraction cycle. If much americium reaches the B-plant strontium recovery solvent 


\section{$-28-$}

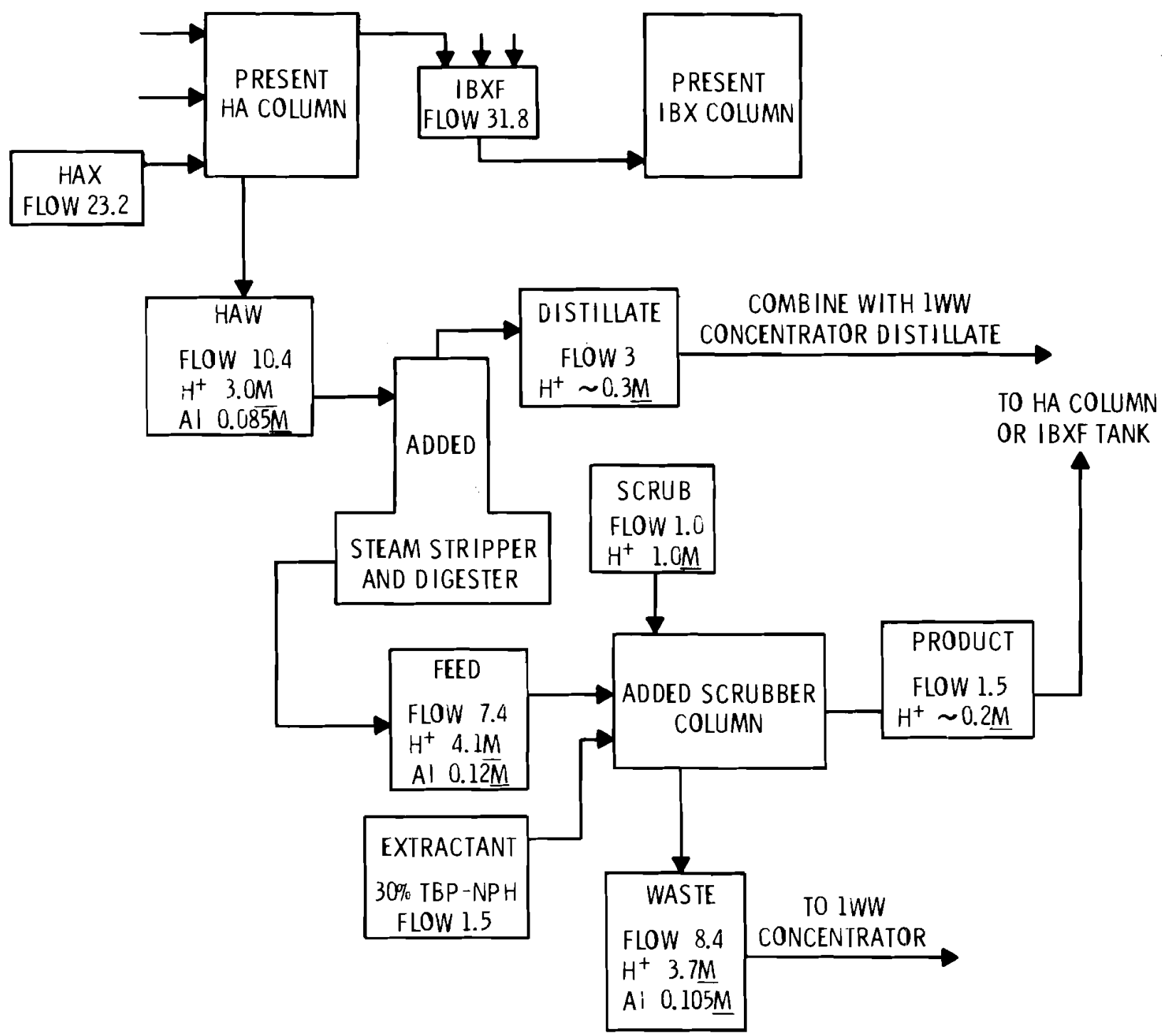

FIGURE 5. Plutonium Digestion and Partitioning for $10 \mathrm{nCi} / \mathrm{g}$ Case 
extraction cycle, however, operation of the B-plant 1B column might have to be modified to assure the low americium contamination in the strontium product stream required to meet the partitioning goal.

Case 4 - Actinide Element Activity About $1 \mathrm{nCi} / \mathrm{g}$ of Solidified Waste

The solvent extraction process shown in Figure 5 to achieve partitioning of plutonium for the $10 \mathrm{nCi} / \mathrm{g}$ case will be adequate for the $1 \mathrm{nCi} / \mathrm{g}$ case if sufficient extraction stages are present and if the feed digestion step is effective in converting at least 99.8 percent of the plutonium to a readily extractable form. The process will also readily give the uranium separation factor of 6 shown in Table $V$ to be necessary for this case but extra provision may be required to attain the $\mathrm{Np}$ decontamination factor of 6 indicated for this case. Adding a small amount of nitrite near the bottom of the added extraction column to catalyze the oxidation of inextractable $\mathrm{Np}(\mathrm{V})$ to extractable NP(VI) (as is normally done in the Purex HA column) would certainly allow the required neptunium decontamination to be attained.

To obtain an americium decontamination factor of 8000 , as is required for this case, would probably require additional equipment and processing over that required for the $10 \mathrm{nCi} / \mathrm{g}$ case. A second cycle of 50 percent TBP-diluent solvent extraction could be added or the B-plant strontium recovery solvent extraction cycle might be modified to improve the americium extraction. Such modifications to give large improvement in americium extraction could well require new equipment for the cycle. Attaining americium recoveries of this level has not been done on a plant scale and any proposed scheme to attain such recovery levels must be considered as outside the realm of established technology; 
VIII. ESTIMATED COSTS OF PARTITIONING HANFORD PUREX PROCESS ACIDIC WASTES

Preliminary cost estimates were made for partitioning Hanford Purex process acid waste to the actinide element removal levels posed for the various cases considered in this study. It must be remembered that these estimates are based on flowsheets which, in some cases, involve technology which has not been used for routine treatment of nuclear wastes. Also, costs for chemical processing equipment and for operating such equipment are escalating rapidly. Hence, the costs arrived at and quoted here must be considered preliminary and very approximate. They probably are significantly low. They are probably useful only for comparison purposes.

Equipment was sized, based on processing the waste from 10 MTU of fuel per day since this corresponds roughly to the present plant capacity. Processing would be on a campaign basis alternated with operation of the Purex plant. The length of a processing campaign would depend on the storage capacity (stainless-steel tanks) for acidic waste available at processing time.

Table VI summarizes the cost data derived for the various residual actinide element concentrations considered in this study. It is apparent the cost for the $1000 \mathrm{nCi} / \mathrm{g}$ case is quite low (\$4/MTU) largely because no structural modifications and very little additional process equipment are required. The unit cost for the other three cases is relatively high ( $\$ 1400$ to $\$ 4200 /$ MTU) primarily because significant structure modification and additional equipment costs are involved. The relatively small amount of processing to be done in these added facilities to process all of the projected Hanford Purex process acid waste results in the high unit cost.

The bases used in arriving at these cost estimates are presented in detail in the Appendix. 
TABLE VI. Summary of Cost Estimates for Partitioning Hanford Purex Acid Waste

\begin{tabular}{l} 
Residual \\
Actinide \\
Elements \\
$n \mathrm{Ci} / \mathrm{g}$ \\
\hline 1 \\
10 \\
100 \\
1000
\end{tabular}

\begin{tabular}{l} 
Cost of \\
Structure \\
Modifica- \\
tions, $1974 \$$ \\
\hline $11,000,000$ \\
$10,000,000$ \\
$4,000,000$
\end{tabular}

\begin{tabular}{l} 
Cost for \\
Additional \\
Processing \\
Equipment, ,1974 \$ \\
\hline $2,250,000$ \\
$2,120,000$ \\
430,000 \\
10,000
\end{tabular}

Operating

Costs Total Cost

Waste from Waste from

1 MTU, $1974 \$ \quad 1$ MTU, $1974 \$$ *

400

4,200

$380 \quad 3,900$

$130 \quad 1,400$

14

ॠ Based on processing waste from 3500 MTU. 


\section{CONCLUSIONS}

Separations procedures were developed which are considered to have good probability of achieving the various degrees of separation of the actinide elements from Hanford Purex process high-level acid waste which were considered in this study. Preliminary estimates of the costs required to implement these procedures in the Hanford separations - waste management complex were made.

The actinide element separation factors required to attain the shortlived fraction actinide element concentrations considered in the study are relatively low (maximum of $10^{4}$ for Am-241). This is because 1) the $\mathrm{N}$-Reactor fuel which will be processed in the Hanford Purex plant will have a low integrated exposure ( 21500 MWD/MT) compared to commercial power reactor fuels and 2) most of the uranium, plutonium and neptunium is recovered in the Purex process. The solvent extraction processes suggested for removing the actinide elements should be capable of producing these separation factors if the actinide elements are truly in solution. However, such processes have not been used in plant or pilot plant operations to attain separation factors greater than about 100. Demonstration of attaining the higher separation factors on a pilot plant or plant scale is needed.

Solids, colloids and inextractable actinide element species which may be present in the Purex high-level waste pose partitioning problems. Similar problems exist for high-level waste from commercial power reactor fuels. Until actual or simulated high-level waste is produced, it is not possible to say to what extent these solids contain actinide elements or what treatment of them is needed to achieve partitioning objectives. Similariy, data on the amount and required treatment of colloids and inextractable species is needed. The treatments proposed in this study are considered to have good probability of solubilizing actinide elements and destroying inextractable species. However, plant scale demonstration of their effectiveness on actual or simulated waste is needed. 
The removal of long-lived fission products from the Hanford Purex process high-level waste was not considered in detail in this study. The presence of long-lived fission products will have to be considered for a complete partitioning facility. Perhaps the most significant fission product in the Purex high-level waste is technetium because of its abundance and its tendency to migrate through soil. Processes potentially capable of removing technetium from the waste are available but have not been applied on a plant scale.

Cost estimates made for implementing the various partitioning processes in the Hanford Purex Plant and B-Plant complex range from $\$ 4$ to $\$ 4,200$ (1974 dollars) to process waste from one ton of fuel. These costs depend on the degree of actinide element removal. Where new facilities and equipment are required, the costs are high because of the short useful life assumed for these additions. However, the costs are much lower than have been estimated for partitioning power reactor fuel wastes (2) partly because of the lower separation factors required and partly because some facilities already exist in the Hanford Purex Plant and B-Plant complex.

A major factor in the potential for partitioning Hanford Purex process acidic high-level waste is timing. If reprocessing the inventory of $\mathrm{N}$-Reactor fuels begins in mid-1976 and if, as assumed in this study, partitioning must be done simultaneously with reprocessing, the lead time for any research and development and for construction of any additional processing facilities is extremely short. 


\section{$X$. REFERENCES}

1. K. J. Schneider and A. M. Platt, Editors, High Level Radioactive Waste Management Alternatives, BNWL-1900, 1974.

2. J. W. Bartlett, Editor, Feasibility Evaluation and R\&D Program Plan for Transuranic Partitioning of High Level Fuel Reprocessing Waste, BNWL-1776, 1973.

3. W. E. Bond, R. E. Leuze, Feasibility of the Partitioning of Commercial High Level Wastes Generated in Spent Nuclear Fuel Reprocessing Annual Progress Report for FY-1974, ORNL-5012, January 1975.

4. H. C. Claiborne, Effect of Actinide Removal on the Long Term Hazard of High-Level Waste, ORNL-TM-4724, January 1975.

5. Separations Process Engineering Staff, Purex Chemical Flowsheet for Processing N-Reactor Fuels, ARH-2362, June 1972.

6. H. H. Van Tuyl, Composition of Some Purex Plant 1WW Samples, HW-57280, August 1958.

7. M. J. Bel1, ORIGEN--The ORNL Isotope Generation and Depletion Code, ORNL-4628, May 1973.

8. E. J. Wheelwright and F. P. Roberts, The Use of Alternating DTPA and NTA Cation-Exchange Flowsheets for the Simultaneous Recovery and Purification of Pm, Am and Cm, BNWL-1072, July 1969.

9. A. L. Boldt and G. L. Ritter, Recovery of $\mathrm{Am}, \mathrm{Cm}$ and Pu from Shippingport Reactor Fuel Reprocessing Wastes by Successive TBP and D2EHPA Extractions, ARH-1354, October 1969.

10. W. W. Schulz and G. L. Richardson, An Integrated Lanthanide - Actinide Solvent Extraction Process, BNWL-SA-3345, June 1970.

11. H. E. Henry, Isolating Am and $\mathrm{Cm}$ from $\mathrm{Al}\left(\mathrm{NO}_{3}\right)_{3}-\mathrm{NaNO}_{3}-\mathrm{HNO}_{3}$ by Batch Extraction with TBP, DP-972, August 1965.

12. M. H. Campbe11, Editor, ARHCO Bimonthly Report, BD Technology Development, Jan.-Feb. 1974, Work by W. W. Schulz, ARH-2901D.

13. B. F. Myasoedov, et al., "Solvent Extraction of Trivalent Americium from Acidic Media," Radiochem. Radioanal. Letters, 14, p. 63 (1973).

14. J. L. McElroy, et al., Waste Solidification Program Summary Report Volume II, Evaluation of WSEP High Level Waste Solidification Processes, BNWL-1667, 1972 . 


\section{APPENDIX}

BASES FOR EST IMATING COSTS FOR PARTITIONING HANFORD PUREX ACID WASTE

Preliminary cost estimates were made for partitioning Hanford Purex process acid waste to the various residual actinide element levels discussed in the body of this report. These estimates include structural modifications and additions, new process equipment required and operating costs. Being based on 1974 dollars, they are undoubtedly significantly low for any future application. The basic flow diagrams for B-plant and Purex plant operations, from which these cost estimates were made are shown in Figures 6,7 , and 8 .

\section{Facility Costs}

Cost estimates for additional process facilities required for the four partitioning cases were based on the process descriptions presented in the body of this report. It was assumed that additional facilities needed would be integrated additions to the existing Hanford Purex and B-plant. only incremental costs for the facilities were considered.

Cel1 space requirements for the additional process equipment for both B-plant and the Purex plant were estimated and are shown in Table VII. sizing of the process equipment and cell space was based on the assumption that waste from processing 10 MTU would be treated per day. No new cel1 space is needed for Case 1 (1000 nCi/g solidified waste). B-plant cell space requirements are the same for the 10 and $100 \mathrm{nCi} / \mathrm{g}$ case while a slightly larger cell is required for the $1 \mathrm{nCi} / \mathrm{g}$ case. Purex plant cell space requirements are the same for the 1 and $10 \mathrm{nCi} / \mathrm{g}$ cases. No new cell space is required for the $100 \mathrm{nCi} / \mathrm{g}$ case.

Cost estimates for these additional processing facilities, including the basic cells and building facilities, are shown in Table VIII.

\section{Process Equipment Costs}

Cost estimates for the additional processing equipment needed in both B-plant and the Purex plant are summarized in Table IX. These data indicate that the cost for processing equipment will be relatively small compared to that for the additional facilities required. 
$-36-$

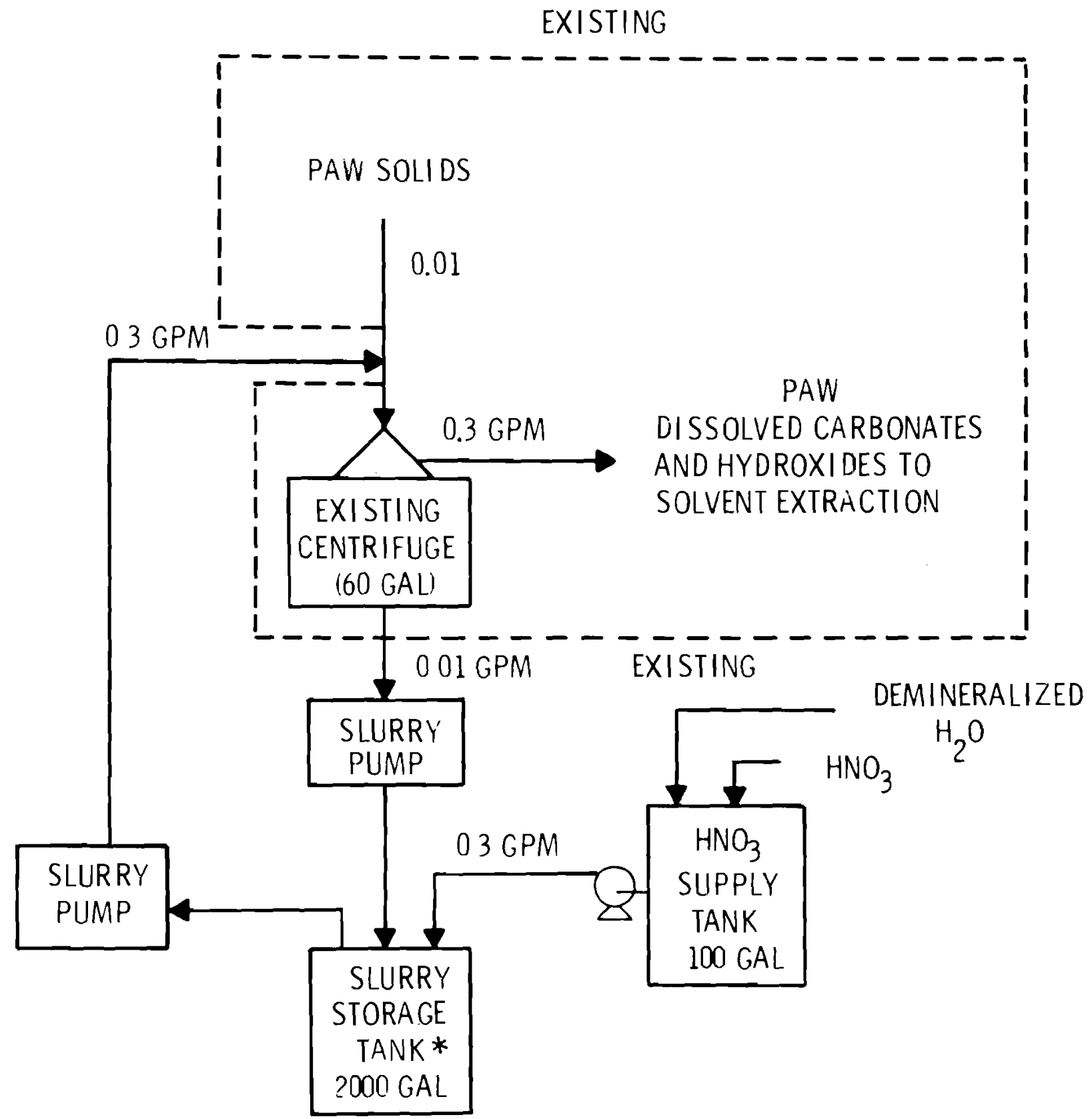

NOTE: THIS TANK MIGHT BE ELIMINATED ONCE ASSURANCE OF LOW AM + LI CONCENTRATION IN THE SLURRY WAS ESTABLISHED 




FIGURE 7. Conceptual Flow Diagram Additional Solvent Extraction System in B-Plant for Partitioning to 10 or $100 \mathrm{nCi} / \mathrm{g}$ 


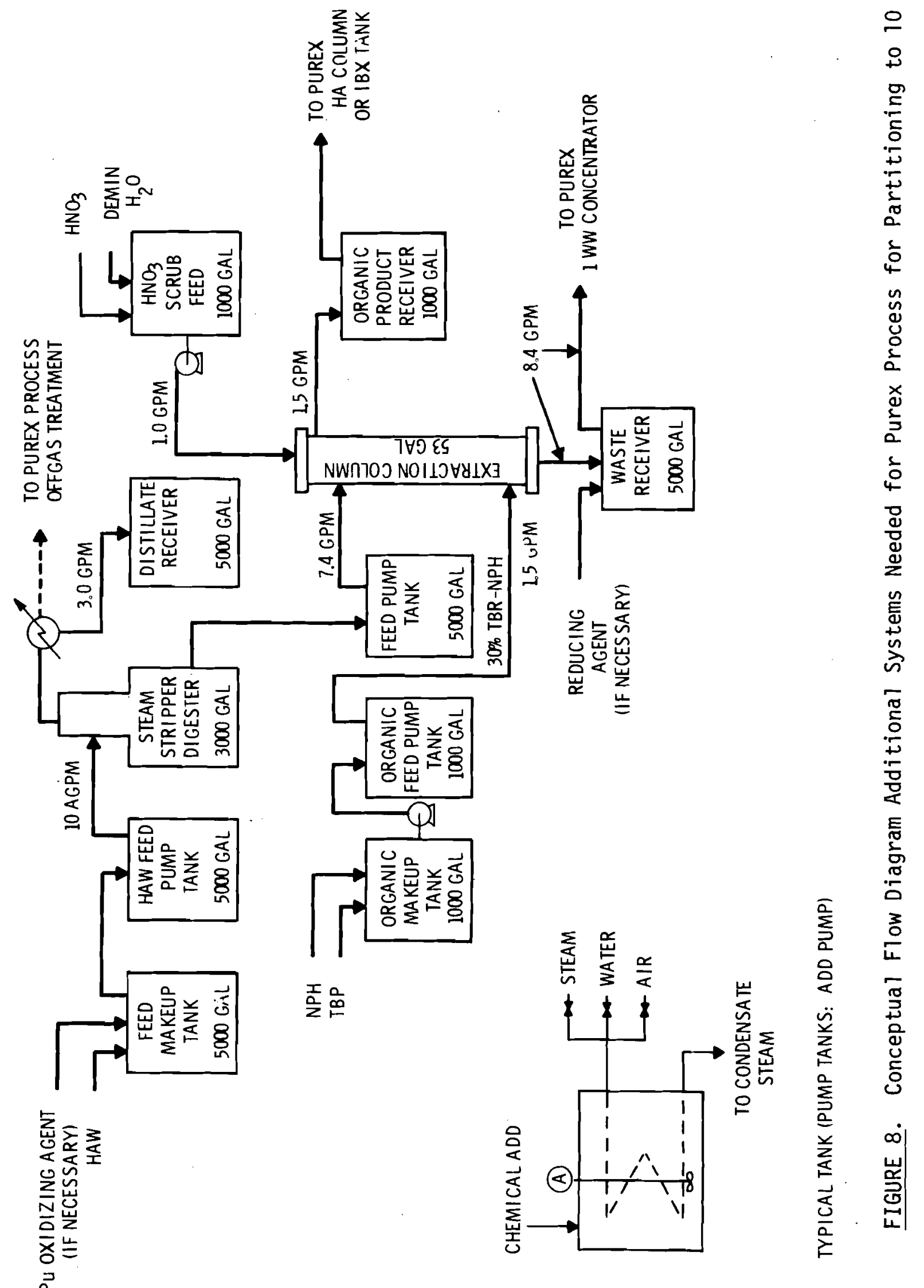


TABLE VII. New Cell Space Requirements for Partitioning Hanford Purex Process Acid Waste

\begin{tabular}{|c|c|c|c|c|c|}
\hline Plant & \multicolumn{2}{|r|}{ Case } & \multicolumn{3}{|c|}{$\begin{array}{l}\text { Dimensions of New Cells, Ft. } \\
\text { Height width }\end{array}$} \\
\hline \multirow[t]{3}{*}{ B-Plant } & (2) & $100 \mathrm{nC} i / g$ & 40 & 14 & 30 \\
\hline & $(3)$ & $10 \mathrm{nCi} / \mathrm{g}$ & 40 & 14 & 30 \\
\hline & $(4)$ & $1 \mathrm{nCi} / \mathrm{g}$ & 40 & 14 & 40 \\
\hline \multirow[t]{3}{*}{ Purex Plant } & $(2)$ & $100 \mathrm{nCi} / \mathrm{g}$ & \multicolumn{3}{|c|}{ None Required } \\
\hline & (3) & $10 \mathrm{nCi} / \mathrm{g}$ & 40 & 14 & 60 \\
\hline & (4) & $1 \mathrm{nCi} / \mathrm{g}$ & 40 & 14 & 60 \\
\hline
\end{tabular}




\section{TABLE VIII. Cost Estimate for Building and Cell Facilities}

\begin{tabular}{|c|c|c|c|}
\hline B Plant & (4)1 nCi/g & (3) $10 \mathrm{nCi} / \mathrm{g}$ & (2) $100 \mathrm{nCi} / \mathrm{g}$ \\
\hline $\begin{array}{l}\text { Structure } \\
\text { Services a } 20 \% \text { of Structure Cost } \\
\text { Misc. A } 10 \% \text { of Structure Cost }\end{array}$ & $\begin{array}{r}1,200,000 \\
240,000 \\
120,000 \\
\end{array}$ & $\begin{array}{r}1,000,000 \\
200,000 \\
100,000 \\
\end{array}$ & $\begin{array}{r}1,000,000 \\
200,000 \\
100,000 \\
\end{array}$ \\
\hline Total: & $1,560,000$ & $1,300,000$ & $1,300,000$ \\
\hline Contractors Overheads at $20 \%$ & 310,000 & 260,000 & 260,000 \\
\hline $\begin{array}{l}\text { Total Structural Cost Including } \\
\text { Services }\end{array}$ & $1,870,000$ & $1,560,000$ & $1,560,000$ \\
\hline $\begin{array}{l}\text { Misc: Preparation, Piping, } \\
\text { Electrical, Instrumentation, } \\
\text { etc. at } 20 \%\end{array}$ & 370,000 & 310,000 & 310,000 \\
\hline $\begin{array}{l}\text { Total Basic Cost Excluding } \\
\text { Process Equipment }\end{array}$ & $2,240,000$ & $1,870,000$ & $1,870,000$ \\
\hline \multirow[t]{2}{*}{ Engineering at $20 \%$} & 450,000 & 374,000 & 374,000 \\
\hline & $2,690,000$ & $2,244,000$ & $1,244,000$ \\
\hline Contingency at $30 \%$ & 807,000 & 670,000 & 670,000 \\
\hline Total cost of Building & $3,497,000$ & 2,914000 & $2,914,000$ \\
\hline Total Cost of Cell Equipment & $1,000,000$ & $\underline{1,000,000}$ & $1,000,000$ \\
\hline TOTAL COST & $4,497,000$ & $3,914,000$ & $3,914,000$ \\
\hline
\end{tabular}

Purex Plant

Structure

Services a $20 \%$ Structure cost

Misc. a 10\% Structure Cost

Total:

Contractors Overheads $+20 \%$

Total Structure Cost Including Services

Misc: Preparation, Piping, Electrical Instrumentation etc. o $20 \%$

Total Basic Cost Excluding Process Equipment

Engineering at $20 \%$

Contingency at $30 \%$

Total Cost of Building

Total Cost of Cell Equipment TOTAL COST

TOTAL COST OF BOTH FACILITIES (Rounded)



The structure cost was based on experience in the BNW Waste Solidification Engineering Prototypes and Volume II BNWL-1667.(14) 
TABLE IX. Summary of Process Equipment Costs

Case

(1) $1000 \mathrm{nCi} / \mathrm{g}$

(2) $100 \mathrm{nCi} / \mathrm{g}$

(3) $10 n \mathrm{Ci} / \mathrm{g}$

(4) $1 \mathrm{nCi} / \mathrm{g}$

1974 Dollars

B-Plant
Modification

10,000

430,000

430,000

560,000
Purex Plant

Modification

$\begin{array}{ll}-- & 10,000\end{array}$

$--$

430,000

$1,690,000$

$2,100,000$

$1,690,000$

$2,250,000$ 
Further details on the equipment needed and associated costs are given in Tables XI, XII, and XIII. Flow diagrams shown in Figures 5,6 and 7 were used as the basis for these estimates. Extraction and stripping columns, and concentrators were sized based on data in the Hanford Purex plant manual (HW-31000). Concentrators and digesters were treated as evaporators with additional tankage for costing purposes. Storage tanks were sized on expected burdens and process tanks were scaled from similar Purex and B-plant operations. The $\$ 10,000$ equipment costs shown for Case 1 $(1,000 \mathrm{nCi} / \mathrm{g})$ is to provide for concentration and separate storage of the B-plant 1BP stream.

Equipment and installation costs were obtained from correlations for pilot-plant equipment costs. Pilot-plant values were used because the correlations tend to give higher costs than normal CPI correlations and reflect "special" construction problems more relevant to nuclear processing facilities. The multiplier of 3 is suggested for this installation instead of the usual CPI value of $1.5-2.0$. This higher value reflects special instrumentation and construction problems and should be more appropriate for this application than the normal CPI value.

Most of the equipment (especially the B-plant modification) falls within the scale of the correlations used. Some extrapolation was necessary for the Purex plant modifications. In all cases, uncertainties in cost were biased to the higher value to provide a conservative estimate. A11 of these cost estimates are based on very preliminary system scoping and flow sheets and should be treated as rough approximations only.

\section{Operating Costs}

Estimated operating costs for the four partitioning cases studies are presented in Table XIV. These are based on estimates of direct labor with maintenance taken as a percent of equipment costs. The costs expressed are for a 100 day campaign at a processing rate equal to the waste from 10 MT of fuel per day. Thus, they are the costs for processing waste from 1,000 MT of fuel. The operating costs for waste from one ton of fuel, as shown in Table VII, are simply 1/1,000 of these estimated costs. 
TABLE X. Equipment $\operatorname{costs}(3)$

$100 \mathrm{nCi} / \mathrm{g}$ Case $^{(2)}$

Description

50 gal process tanks $(1)$

100 gal process tanks

200 ga 1 process tanks

2,000 gal storage tanks

250,000 gal storage tanks

0.1 GPM pump

1.0 GPM pumip

2.0 GPM pump

5.0 GPM pump

1 GPM slurry pumps

$1 \mathrm{ft} 0 \times 9 \mathrm{ft}$ column

$1 / 2 \mathrm{ft} 0 \times 4 \mathrm{ft}$ column

TOTAL
BASIS: $10 \mathrm{MT} / \mathrm{day}$

\begin{tabular}{crr} 
Quantity & Unit Cost & Total Cost \\
\hline 5 & 1,000 & 5,000 \\
12 & 1,250 & 15,000 \\
3 & 2,000 & 6,000 \\
1 & 2,700 & 2,700 \\
1 & 100,000 & 100,000 \\
4 & 500 & 2,000 \\
7 & 800 & 5,600 \\
1 & 800 & 800 \\
1 & 1,000 & 1,000 \\
2 & 900 & 1,800 \\
1 & 2,300 & 2,300 \\
1 & 1,200 & 1,200 \\
\hline & & 143,400
\end{tabular}

$X 3$ for piping instrumentation, individual supports, electrical, insulation, and painting

TOTAL

1. All process tanks assumed to have agitator and coil.

2. Includes Purex and B-Plant modifications.

3. A11 equipment costs are FOB Richland in June 1974. 
TABLE XI. Equipment Costs ${ }^{(3)}$

$10 \mathrm{nCi} / \mathrm{g}$ Case $^{(2)}$

Description

50 gal process tanks $(1)$

100 gal process tanks

200 gal process tanks

1,000 gal process tarks

3,000 gal process tanks

5,000 gal process tanks

2,000 gal storage tanks

250,000 gal storage tanks

$0.1 \mathrm{gpm}$ pumps

$1.0 \mathrm{gpm}$ pumps

$2.0 \mathrm{gpm}$ pumps

$5.0 \mathrm{gpm}$ pumps

$10.0 \mathrm{gpm}$ pumps

$1 \mathrm{gpm}$ slurry pumps

$1 \mathrm{ft} \times 9 \mathrm{ft}$ columns

$1 / 2 \mathrm{ft} \times 8 \mathrm{ft}$ columns

100 gallon concentrators

3,000 gallon digester

TOTAL
BASIS: $10 \mathrm{MT} /$ day

\begin{tabular}{|c|c|c|}
\hline Quantity & Unit Cost & Total \\
\hline 5 & 1,000 & 5,000 \\
\hline 12 & 1,250 & 15,000 \\
\hline 3 & 2,000 & 6,000 \\
\hline 4 & 5,000 & 20,000 \\
\hline 1 & 25,000 & 25,000 \\
\hline 5 & 90,000 & 450,000 \\
\hline 1 & 2,700 & 2,700 \\
\hline 1 & 100,000 & 100,000 \\
\hline 4 & 500 & 2,000 \\
\hline 8 & 800 & 6,400 \\
\hline 2 & 800 & 1,600 \\
\hline 1 & 1,000 & 1,000 \\
\hline 2 & 2,000 & \\
\hline 2 & 900 & 1,800 \\
\hline 2 & 2,300 & 4,600 \\
\hline 1 & 1,900 & 1,900 \\
\hline 1 & 19,000 & 19,000 \\
\hline 1 & 45,000 & 45,000 \\
\hline & & 707,000 \\
\hline
\end{tabular}

X3 for piping, instrumentation, individual supports, electrical, insulation, and painting

TOTAL:

$\underline{\underline{2,131,000}}$

1. All process tanks assumed to have agitator and coil.

2. Includes Purex and B-Plant modifications. 
TABLE XII. Equipment Costs ${ }^{(3)}$

$1 \mathrm{nCi/g}$ Case $^{(2)}$

Description

50 gallon process tanks (1)

100 gallon process tanks

200 gallon process tanks

1,000 gallon process tanks

3,000 gallon process tanks

5,000 gallon process tanks

2,000 gallon storage tanks

250,000 gallon storage tanks

$0.1 \mathrm{gpm}$ pumps (1iquid)

$1.0 \mathrm{gpm}$ pumps (1 iquid)

$2.0 \mathrm{gpm}$ pumps (1 iquid)

$5.0 \mathrm{gpm}$ pumps (1 iquid)

$10 \mathrm{gpm}$ pumps (1 iquid)

$1 \mathrm{gpm}$ slurry pumps

$1 \mathrm{ft} \times 9 \mathrm{ft}$ columns

$1 / 2 \mathrm{ft} \times 8 \mathrm{ft}$ columns

100 gallon concentrators

3,000 gallon digestor

Subtota 1:

X3 for piping, instrumentation, individual supports, electrical, insulation, and painting

TOTAL
BASIS: $10 \mathrm{MT} /$ day

Quantity Unit Cost Total

9

9
12

1,000

9,000

15,000

12,000

20,000

25,000

450,000

2,700

100,000

2,000

8,000

1,600

2,000

2,000

1,800

6,900

3,800

19,000

45,000

750,100

$\underline{\underline{2,250,000}}$

1. A11 process tanks assumed to have agitator and coil.

2. Includes Purex and B-Plant modifications.

3. Al1 equipment costs are FOB Richland in June 1974. 
TABLE XIII. Estimated Partitioning Operating Costs for a 100 Day Campaign 1974 Dollars

\begin{tabular}{cccc} 
Case 1 & Case 2 & Case 3 & Case 4 \\
$1,000 \mathrm{nCi} / \mathrm{g}$ & $100 \mathrm{nCi} / \mathrm{g}$ & $10 \mathrm{nCi} / \mathrm{g}$ & $1 \mathrm{nCi} / \mathrm{g}$ \\
\hline
\end{tabular}

B-Plant

Operating Labor $(a)$

Supervision $(b)$

$\begin{array}{lrrr}-- & 28,800 & 28,800 & 28,800 \\ -- & 5,000 & 5,000 & 5,000\end{array}$

Maintenance a $10 \%$ of

Equipment cost

$\begin{array}{lrrr}1,000 & 43,000 & 43,000 & 55,900 \\ - & 33,800 & 33,800 & 33,800 \\ - & \frac{10,000}{120,600} & \frac{10,000}{120,600} & \frac{15,000}{138,500}\end{array}$

Purex Plant

Operating Labor (a)

Supervision (b)

Maintenance o 100 of

Equipment cost

Plant Overhead $100 \%$ of

Direct Labor

\begin{tabular}{|c|c|c|c|}
\hline - & - & 28,800 & 28,800 \\
\hline- & - & 5,000 & 5,000 \\
\hline- & - & 169,000 & 169,000 \\
\hline- & - & 33,800 & 33,800 \\
\hline- & - & 10,000 & 10,000 \\
\hline 1,000 & 120,600 & 367,200 & 385,100 \\
\hline
\end{tabular}

a. 1 man year $=\$ 12,000$

b. 1 man year $=\$ 14,000$ 


\section{DISTRIBUTION}

No. of

Copies

OFFSITE

1 ERDA Chicago Patent Group Chicago Operations Office 9800 South Cass Avenue Argonne, IL 60439

A. A. Churm

201 ERDA Technical Information Center

4 ERDA Division of Production and Materials Management USERDA Headquarters Germantown, MD 20014

F. P. Baranowski

W. L. Lenneman

J. W. Pollock

D. E. Saire

6 ERDA Division of Waste Management and Transportation USERDA Headquarters Germantown, MD 20014

G. H. Daly

0. P. Gormley

H. F. Perge

F. K. Pittman

R. W. Ramsey

R. D. Walton

1 ERDA Division of Reactor Research arid Development USERDA Headquarters Germantown, MD 20014

W. H. McVey

1 ERDA Division of Physical Research 3 USERDA Headquarters Germantown, MD 20014

W. J. Haubach
No. of

Copies

1 ERDA Oak Ridge Operations Office P.0. Box E Oak Ridge, TN 37830

J. J. Schrieber

1 ERDA Savannah River Operations Office

P.0. Box A

Aiken, SC 29801

R. L. Chandler

1 ERDA Idaho Operations Office

P.0. Box 2108

Idaho Falls, ID 83401

K. K. Kennedy

1 Sandia Laboratories

P.0. Box 5800

A1buquerque, NM 87115

R. Schwoebel

3 Holifield National Laboratory P.0. Box X

Oak Ridge, TN 37830

J. 0. Blomeke

R. E. Leuze

R. G. Wymer

2 E. I. du Pont de Nemours and Company Savannah River Plant Aiken, SC 29801

W. H. Hale

A. S. Jennings

Allied Chemical Corporation Idaho Chemical Programs Operations Office P.0. Box 2204 Idaho Fal1s, ID 83401

J. A. Buckham

C. M. Stansky

L. D. McIsaac 
No. of

Copies

ONSITE

1 ERDA-RL
R. M. Poteat

5 ERDA Richland Operations Office Production and Waste Management Programs Division

0. J. Elgert

R. B. Goranson

J. L. Rhoades

Research and Development Programs Division

B. J. Melton

Environmental, Safety and Technical Services Division

P. J. Holstead

6 Atlantic Richfield Hanford Company
H. Babad
D. R. Gustavson
H. P. Shaw
W. W. Schulz
D. D. Wodrich
ARHCO Files

1 United Nuclear Industries, Inc. UNI Files

4 Westinghouse Hanford Company
C. R. Cooley
R. E. Lerch
G. L. Richardson
WHCO Files

No. of

Copies

23 Battelle-Northwest

T. W. Ambrose

R. E. Burns

J. N. Hartley

J. H. Jarrett

M. R. Kreiter

D. H. Lester

J. L. McElroy

R. E. Nightingale

A. M. Platt (3)

F. P. Roberts

K. J. Schneider

J. L. Swanson

H. H. Van Tuyl

E. J. Wheelwright (4)

Technical Information (3)

Technical Publications 